\title{
Ankara Üniversitesi Türk İnkılâp Tarihi Enstitüsü Tarihçesi ve Gelişim Süreci
}

\author{
Dr. Necdet AYSAL*
}

Ankara Üniversitesi Türk İnkılâp Tarihi Enstitüsü, Atatürk'ün önderliğinde gerçekleştirilen inkılâp hareketinin çağdaş bir biçimde incelenmesi ve genç kuşaklara öğretilmesi amacına yönelik olarak 4204 sayılı Yasa ile 15 Nisan 1942'de kurulan bir araştırma, eğitim ve öğretim merkezidir.

Türkiye Cumh'riyeti Devleti'nin kurucusu Gazi Mustafa Kemal Atatürk, Cumhuriyetin ilanı sonrası toplumu çağdaş medeniyetler seviyesine ulaştırmak için her alanda köklü devrim hareketlerine girişmiştir. Büyük tarihsel dönüşümün sürekliliğini sağlayacak düşünsel ve kültürel temelleri oluşturmaya yönelen Atatürk'ün, eğitim ve öğretimle birlikte yeni devletin ideolojisine uygun olarak "Milli Tarih" ve "Milli Dil" çalışmalarına da ağırlık verdiği görülmektedir.

İnkılâp Tarihi Dersleri'nin öğretimi, 1929 Dünya ekonomik krizi ve onu izleyen 1930 demokrasi denemesinin sonucunda gündeme getirilmiştir. Atatürk, Serbest Cumhuriyet Fırkası'nın kapatıldığı gün üç ay sürecek bir yurt gezisine çıkmış ve bu inceleme gezisinde Cumhuriyet rejiminin aleyhindeki hareketlerin önlenmesine ve bu yönetimin pekiştirilmesine yönelik notlar almıştır. Bu izlenimlerini hükümete sunan Atatürk'ün, bu yönde alınması gereken önlemlerden birini şöyle not ettirdiği görülmektedir": “...Bir Cumhuriyeti ve rejimi koruma kanunu neşredilmelidir. Bu kanunda, bizzat Cumhuriyet aleyhinde olduğu gibi onun temellerini teşkil eden inkılâp kanunları aleyhinde fiilen harekete teşvik veyahut bu konuda söz ve yazı ile telkin, ă̆ır ceza müeyyidelerine bağlanmalıdır..."

* Ankara Üniversitesi Türk İnkılap Tarihi Enstitüsü Öğretim Görevlisi

' Mustafa Oral, "Türk İnkılap Tarihi Enstitüsü 1933", Atatürk Yolu, C. 7, No. 27-28, (Mayıs-Kasım 2001), s. 324; Atatürk'ün Seyahat Notları (1930-1931), Haz., Gürbüz Tüfekçi, İstanbul, Kaynak Yayınları, 1988, s. 84. 
Cumhuriyet onuncu yılını doldurduğunda yetişmekte olan kuşaklara Atatürk'ün anlatımıyla, “...Ulusal varlığı sona ermiş sayılan bir ulusun bağımsızlığını nasıl kazandığını, bilim ve tekniğin en son ilkelerine dayanan ulusal, çă̆daş bir devleti nasıl kurduğunu” öğretmenin gerekli olduğuna karar verilmişti. Bu amaçla Ankara Hukuk Mektebi'nde bir “Ínkılâp Tarihi Kürsüsü” kurulmuş ve derslerin yüksek öğretimdeki son sınıf öğrencilerine konferans biçiminde verilmesi yeterli görülmüştür ${ }^{2}$.

Ankara Hukuk Mektebi'ndeki ilk İnkılâp Tarihi konferansını 20 Mart 1934'te Başbakan İsmet İnönü vermiştir. İnönü'nün bu konferansı, söz konusu dersin niteliğini ve çerçevesini açıkça ortaya koymaktadır. Türk İnkılâbını "Türk Milletinin Kurtuluş Savaşı" olarak nitelendiren İnönü, bu mücadelenin önemli aşamalarını bu dersleri verecek öğretim üyelerinin anlatacağını ve bunun devamı için, başlıca iki önemli hususa dikkat edilmesi gerektiğini şöyle vurgulamıştır": “...Devrimlerden hiçbir şekilde ödün vermemek, geriye dönüş yapmamak ve Türk Milletinin yüksek bir düzeye ulaşması için ihtiyaçlarının karşılanmasını sağlamak ve bu amaca ulaşmak için çıkabilecek her engeli ortadan kaldırmak..."

$\mathrm{Bu}$ işlerin gerçekleştirilebilmesi için yetişmiş uzman, öğretmen ve öğretim üyesine ihtiyaç vardı. Bu eksikliği tamamlamak için 20 Haziran 1935 'te kuruluş yasası Resmi Gazete'de yayınlanan Dil ve Tarih-Coğrafya Fakültesi, 9 Ocak 1936' da eğitim ve öğretime başlamıştır ${ }^{4}$.

Hasan Âli Yücel, Milli Eğitim Bakanı olarak görev yaptığı dönemde (1938-1946) özverili çalışmalarıyla Atatürkçü ilkeler doğrultusunda bir ulusal bilinç yaratmış ve bireyler arasındaki iletişimi sağlamıștır ${ }^{5}$. Bunun en güzel örneği de bakanlığı zamanında kuruluşu gerçekleşen "Türk Inkılâp Tarihi Enstitüsü" dür.

$\mathrm{Bu}$ dönem içerisinde yükseköğretim kurumlarında konferans biçiminde verilen İnkılâp Tarihi derslerinden beklenen sonucun alınamadığı görülünce, bunun belirli bir programla ve yetkin kişilerce sürdürülmesinin gerektiği anlaşılmıştır. Cumhurbaşkanı İsmet İnönü, 1 Kasım 1941'de TBMM'yi açış konuşmasında bu eksikliği şu sözlerle dile getirmiştir ${ }^{6}$ :

${ }^{2}$ Şerafettin Turan, İsmet İnönü, Yaşamı, dönemi ve Kişiliği, Ankara, Bilgi Yayınları, 2000, s. 164-165.

3 “İnkılâp Kürsüsü'nde İsmet Paşa'nın Dersi”, Ưlkü, C. III, No. 14, (Nisan 1934), s. 184-190.

4 “Ankara'da Bir Dil ve Tarih-Coğrafya Fakültesi Kurulması Üzerine Kanun”, Resmi Gazete, No. 3033, 20 Haziran 1935, s. 5372.

${ }^{5}$ Mustafa Çıkar, Hasan Âli Yücel ve Türk Kültür Reformu, Ankara, Türkiye İş Bankası Kültür Yayınlan, 1997, s. 11.

${ }^{6}$ Milli Şefin Söylev ve Demeçleri, Der. K. Kemal Kop, Ankara, 1945, s. 107; Turan, s. 165 . 
“...Şimdiye kadar Yüksek Öğretim Kurumları'nın son sinıflarında konferans seklinde verilmekte olan Inkılâp derslerinin, bu kurumlarda 'Inkılâp Tarihi ve Türkiye Cumhuriyeti Rejimi' adı altında esaslı bir ders şeklinde verilmesi ve mevzular etrafinda ilmi incelemeler yapmak ve yaymak üzere bir de 'Inkılâp Tarihi ve Türkiye Cumhuriyeti Enstitüsü' kurulması kararlaştırılmıştır..."

Bu çalışmalar doğrultusunda hazırlanan yasa tasarısı, 15 Nisan 1942'de Meclis'çe kabul edilerek 4204 sayı ile yasalaşmıştır. Söz konusu yasada kuruluşun adı, "Türk İnkılâp Tarihi Enstitüsü" olarak saptanmıştır? . Enstitü, Dil ve Tarih-Coğrafya Fakültesi'nin giriș holü sonundaki "Atatürk Locası" diye anılan bölüme yerleştirilmiş ve Müdürlüğüne de Prof. Dr. Enver Ziya Karal atanmıştır ${ }^{8}$.

Enstitü, Kurtuluş Savaşı'ndan başlayarak Cumhuriyet dönemine ilişkin her türlü belge ve bilgiyi toplama, bu döneme ilişkin bilimsel araştırmalar ve yayınlar yapma yanında, Milli Eğitim Bakanlığı ile işbirliği yaparak, İnkılâp Tarihi ve Türkiye Cumhuriyeti Rejimi derslerinin programlarını hazırlamak ve bu dersleri verecek kişileri belirlemekle yükümlü kılınmıştı.

Dil ve Tarih-Coğrafya Fakültesi'ne bağlı olarak açılışı gerçekleşen Enstitü'nün kuruluş amacı, yönetmeliğinde şu şekilde açıklanmaktadır':

"Türk İstiklâl Savaşı, Türk İnkılâbı ve Türkiye Cumhuriyet rejiminin dayandı̆̆ı esaslar hakkında her türlü araştırmalarda bulunmak; bu konularla ilgili belgeleri ve yayınları toplayarak kütüphane ve müzeler meydana getirmek ve bir arşiv kurmak; Türk Inkılâp ve Rejimini memleket içinde ve dişında tanıtmak için dersler ve konferanslar vermek ve her türlü yayınlarda bulunmak..."

$\mathrm{Bu}$ amaçlar doğrultusunda çalı̧̧malarına başlayan Enstitü, Kurtuluş Savaşı, Türk Devrimi ve Türkiye Cumhuriyet rejimine ait kitap, arşiv belgeleri ve eşyaları toplamaya başlamıştır. Bu tür malzemeler toplanırken 14 Ocak 1942'de kabul edilen tasarıdaki genel hükümler dikkate alınmıştır. Adı geçen tasarıda şöyle bir hüküm yer almaktadır ${ }^{10}$ : “...Bütün resmi ve milli makam ve kurumlar, kendi dosya ve arşivlerinde bulunan İnklâp Tarihi ile ilgili her nevi evrak ve belgelerin asıl veya kopyalarını Maarif Vekilliği tarafindan gerek duyuldukça, bu Enstitüye vereceklerdir..."

7 “Ankara Dil ve Tarih-Coğrafya Fakültesi'ne Bağlı 'Türk İnkılap Tarihi Enstitüsü' Kurulması Hakkında Kanun”, Resmi Gazete, No. 5090, 22 Nisan 1942.

${ }^{8}$ Ankara Üniversitesi Dil ve Tarih-Coğrafya Fakültesi 66. Kuruluş Yıldönümü Anı Kitabı, Yay. Haz., Kıymet Giray-Hakan Kaderoğlu, Ankara, AÜ. Basımevi, 2003, s. 215.

${ }^{9}$ Resmi Gazete, 22 Nisan 1942, No. 5090.

${ }^{10}$ Cumhuriyet, 14 Ocak 1942, s. 1 . 
Türk İnkılâp Tarihi Enstitüsü, kendisi için gerekli malzemeyi toplamak amacıyla dönemin gazetelerine ilanlar da vermiştir. "Türk Inkılâp Tarihi Enstitüsü, Istiklâl Savaşı'na Ait Bütün Eserleri Topluyor" başlıklı gazete ilanlarında, bu materyallere ait bilgiler ayrıntılı bir şekilde dile getirilmektedir ${ }^{11}$.

Yeni kurulan Türk İnkılâp Tarihi Enstitüsü Müdürlügüu, bütün illere birer genelge göndererek, Kurtuluş Savaşı ve Devrim Tarihimizle ilgili her türlü belge ve eşyaların toplanmasını istemiştir. Bağışta bulunanların adları Enstitünün şeref defterine kaydedilecek, resmi gazetede ilan edilecek, ayrıca kendilerine "Şeref Diploması" adıyla Enstitü tarafından bir diploma verilecektir. Ancak Enstitü, bu eşyaları bu şekilde vermeyen, satmak isteyenlerden de eşyaları değeri üzerinden satın alacaktır. Enstitünün istediği eserler şunlardır 12: "Milli Savaşa ait her türlü eşya, önemli belgeler, Şapka Devrimi, bundan önceki kadın ve erkek giysileri, yazı ve dil devrimi ile ilgili malzemeler, Devrim Tarihine ait istatistikler, grafikler, sulu boya tablolar, resimler, Devrim adamlarina ait resimler, eserler ve belgelerdir."

Diğer yandan Ulusal Bağımsızlık Savaşı'na katılan ve bu savaşta görev alan kişilere de yazılar yazılarak ellerindeki materyalleri Enstitüye vermeleri istenmiştir ${ }^{13}$. Bugün Türk İnkılâp Tarihi Enstitüsü bünyesinde bulunan kitap, arşiv belgeleri, fotoğraflar ve müze malzemeleri, bu süreçlerden geçerek ve bu tür uğraşılar sonucu elde edilmiştir. BL çalışmalar sonucunda Dışişleri Bakanlığı, Polis Enstitüsü, Afyon, Bitlis, Konya, Kırşehir, İzmir, Urfa, Muğla, Eskişehir, Erzurum Valilikleri ile Bekir Sıtkı Baykal, Refet Bele, Hacim Muhittin Çarıklı, Kâzım Karabekir, Hüsrev Gerede, Avni Gelendost, Rahmi Apak, Fahri Belen, Enver Behnan Şapolyo, Gıyas Yetkin ve Behiç Erkin Bey gibi şahıslar, Enstitümüze önemli miktarda arşiv belgesi, kitap ve müzelik eşya bağışlamışlardır ${ }^{14}$.

4204 sayılı Yasa, Türk İnkılâp Tarihi Enstitüsü Yönetim Kurulu'na tek partili dönemin özelliği gereği, CHP'den de bir temsilci alınmasını öngördügüünden 1946'da çok partili siyasal yaşama geçildiğinde, Enstitünün çalışamaz duruma geldiği görülmüştür. Yıllarca yasada gereken değişikliğin yapılması beklenmiş ama değişiklik gerçekleşmemiştir. 12 Eylül 1980 sonrası yürürlüğe giren Yüksek Öğretim Kurulu (YÖK) Yasası ile 4204 sayılı Yasa tümüyle yürürlükten kaldırılmıştır. Bu değişiklikle birlikte Türk İnkılâp Tarihi Enstitüsü, Ankara Üniversitesi Rektörlügüu'ne bağlanmıştır. Enstitü, bugün kuruluş amacına uygun olarak çalışmalarını bu statü içinde sürdürmektedir.

\footnotetext{
"AÜ. Türk Inkılap Tarihi Enstitüsü Arşivi, Kutu No. 93, Gömlek No. 30, Belge No. 3046.

${ }^{12}$ TiTE Arşivi, Belge No. 30-46.

${ }^{13}$ TiTE Arşivi, Kutu No. 71, Gömlek No. 27, Belge No. 27, (17 Kasım 1944).

${ }^{14}$ Mustafa Toker, "Türk İnkılap Tarihi Enstitüsü Bağışlarınızı Bekliyor”, Atatürk Yolu, C. 7, No. 25-26, (Mayıs-Kasım 2000), s. 247-250.
} 
Türk İnkılâp Tarihi Enstitüsü Müdürlüğü, şu anda Ziraat Fakültesi yerleşkesi içinde "Gıda Mühendisliği 4 Nolu bina, Keçiören" adresinde çalışmakta olup, ayrıca Dil ve Tarih-Coğrafya Fakültesi içinde bulunan arşiv, müze ve zengin kütüphanesiyle araştırmacılara hizmet vermektedir. Enstitünün arşiv ve kütüphanesinde bugün 9.000 civarında kitap, gazete, fotoğraf, pul koleksiyonları ve çok sayıda arşiv belgesi bulunmaktadır. Arşiv belgelerinin bilgisayara uyarlı analitik tasnifine başlanmış ve bugüne kadar "TITE-Arşivi" adı altında dokuz cilt katalog hazırlanarak araştırmacıların yararlanmasına sunulmuştur. Basımı da gerçekleştirilen dokuz cilt katalog, Türkiye'deki bütün üniversite kütüphanelerine ücretsiz olarak gönderilmiştir. Tasnif ve katalog çalışmalarına halen devam edilmektedir. Tasnif işlemi tamamlandığında kataloglar ve belgeler elektronik ortama açılacaktır.

Enstitü arşiv ve kütüphane bünyesinde bulunan ve gerek kullanım, gerekse $1 S 1$, 1şık, nem, toz, bakteri ve mantar gibi etkenlerle yıpranmış olan belge ve kitapları onarmak ve araştırmacılara tekrar kazandırmak amacıyla, "Belge Bakım ve Onarım Projesi" adı altında bir çalışma başlatılmıştır. Bu proje kapsamında ilk aşamada arşiv belgelerinin, ikinci aşamada eski gazetelerin, son aşamada ise kitapların bakım ve onarımının yapılması planlanmıştır.

Enstitümüz bünyesinde yer alan Devrim Tarihi Müzesi de haftanın çalışma günlerinde ziyaretu̧ilere açıktır. Bu müzenin oluşturulma düşüncesi, Enstitü açılmadan önce 1925 yılında dönemin Milli Eğitim Bakanı Hamdullah Suphi Tanriöver tarafından Etnografya Müzesi'nin kuruluş çalışmaları sırasında, Mehmet Fuat Köprülü tarafından gündeme getirilmiştir ${ }^{15}$. Etnografya Müzesi bünyesinde kurulması düşünülen "İnkılâp Şubesi" ile Türk İnkılâp Tarihinin bir araştırma merkezi konumuna getirilmesi düşünülmüştür ${ }^{16}$. Bu düşünceden hareketle ciddi anlamda hazırlıklar yapılmış ve İnkılâp Şubesi'nde sergilenmek amacıyla toplanacak eserlerin niteliğine ilişkin çalışmalara hız verilmiştir. Bu amaçla müzenin oluşturulmasında aranan materyallerin, "Ulusal Bağımsızlık Savaşı ve Türk Devrimi ile ilgili her türlü eser ve hatıralar" olmas1 istenmiştir. Bu çalışmaların yanı sıra müzede toplanacak eserlere ilişkin 1927'de bir kılavuz (Tüzük) hazırlanmış ve bu kılavuzda, Kurtuluş Savaşı ve Devrimler dönemine ilişkin her türlü görsel ve yazılı belgelerin ve özellikle Atatürk'e ait olanların toplanmasının ve sergilenmesinin önemi vurgulanmıştır ${ }^{17}$.

Etnografya Müzesi içerisinde bir "İnkılâp Şubesi" oluşturma çabaları 1940'lı yıllara kadar devam etmiş, fakat olumlu bir sonuç alınamamıştır.

${ }^{15}$ Mehmet Önder, Türkiye Müzeleri, Ankara, Kültür Yayınları, 1999, s. 11-13.

${ }^{16}$ TiTE Arşivi, Belge No. 24/146, (14 Şubat 1928); Mustafa Oral, "Ankara Etnoğrafya Müzesi İnkılâp Şubesi”, Atatürk Yolu, C. 8, No. 29-30, (Mayıs-Kasım 2002), s. 119-120.

${ }^{17}$ Başbakanlık Cumhuriyet Arşivi, "Türkiye Cumhuriyeti Maarif Vekâleti Milli Talim ve Terbiye Dairesi, Etnoğrafya Müzesi İnkılâp Şubesi'ne Kabul Olunacak Asâra Dair”, 030. 10. 213.445 .9 . 
1927 tarihli "Etnografya Müzesi İnkılâp Şubesine Kabul Olunacak Asâra Dair" başlıklı tüzük çerçevesinde yürütülen çalışmalarla elde edilen tarihi ve müzelik malzemeler ise, 15 Nisan 1942'de Dil ve Tarih-Coğrafya Fakültesi bünyesi içerisinde kurulan Türk İnkılap Tarihi Enstitüsü'ne ait “Devrim Tarihi Müzesi"ne taşınmıştır.

Enstitümüz, kuruluşundan bugüne kadar çok sayıda eserin hazırlanmasına katkıda bulunmuştur. Süreli yayınlarından birisi olan "Atatürk Yolu" dergisi, yılda iki kez (Mayıs-Kasım) yayımlanmakta olup, şu ana kadar otuz sayı çıkarılmıştır. Adı geçen dergimiz, Mayıs 2002 tarihinden itibaren "Hakemli Dergi" statüsünde yayımını sürdürmektedir. Enstitümüzde, Ankara Üniversitesi'ne bağlı fakülte ve yüksekokulların birinci sınıflarında okutulmakta olan "Atatürk İlkeleri ve İnkılap Tarihi" dersinin koordinasyonu, öğretim elemanlarının sağlanması, ders plân ve programlarının hazırlanması yanında "Yüksek Lisans ve Doktora" eğitimi çalışmaları da devam etmektedir. Enstitümüz bünyesinde zaman zaman dizi konferanslar verilmekte ve araştırma, yayın çalışmaları sürdürülmektedir.

Türk İnkılap Tarihi Enstitüsü, bilimsel araştırma açısından olanakları ve potansiyeli ile Türkiye'deki İnkılap Tarihi Enstitüleri içinde en zengin olanıdır. Atatürk'ün istek ve direktifleri doğrultusunda çalışmalarını sürdüren “Türk İnkılap Tarihi Enstitüsü"nde, kuruluşundan bugüne kadar "Müdï liik Görevi"nde bulunan değerli öğretim üyeleri şunlardır:

\section{Ord. Prof. Dr. Enver Ziya Karal:}

1906 yılında Kosova'nın Osmaniye kasabasında doğmuştur. 1933-1940 tarihleri arasında İstanbul Üniversitesi Edebiyat Fakültesi'nde "Yakınçağ Tarihi Doçenti" olarak görev yapmıştır. 1940 yılında Ankara'da Dil ve Tarih-Coğrafya Fakültesi'ne naklen atanan Karal, 1941 yılında "Yakınçağ Tarihi Profesörlüğü"ne ve 1960 'da ise “Ordinaryüs Profesörlüğe” terfi ettirilmiştir. Ord. Prof. Dr. Enver Ziya Karal, Türk Inkılap Tarihi Enstitüsü'nün kuruluş çalışmalarında aktif olarak görev almış ve 1942-1945, 1949-1956, 1959-1960 tarihleri arasında adı geçen Enstitünün Müdürlük görevini de üstlenmiştir. Enstitü Müdürlüğ̈̈'nün yanı sıra Dil ve TarihCoğrafya Fakültesi Dekanlığı (1946-1948), Ankara Üniversitesi Rektörlüğg̈ (1948-1950), Anayasa Komisyon Başkanlığı (1960-1961) ve Türk Tarih Kurumu Başkanlığı (1972-1978) görevlerinde de bulunmuştur. Türk Tarih Kurumu, Türk Dil Kurumu ve Unesco Üyesi olan Karal, dünyanın çeşitli ülkelerinde dersler vermiş ve Osmanlı-Türkiye Cumhuriyeti Tarihi ile ilgili pek çok eseri kaleme almıştır. Ord. Prof. Dr. Enver Ziya Karal 1982 yılında vefat etmiştir.

\section{Prof. Dr. A. Afet İnan:}

1908 yılında Selanik'in Doyran Kazası'nda doğmuştur. 1925 yılında Bursa Kız Öğretmen Okulu'ndan mezun olan İnan, aynı yıl Lozan'a Fransızca öğrenmeye gitmiştir. 1929'da Ankara Musîkî Muallim Mektebi’de 
"Tarih ve Yurt Bilgisi" dersleri okutmaya başlamıştır. Bu okulda ögretmenliğe devam ederken yabancı dillerdeki bazı tarih kitaplarından okuduğu Türk ulusu için kullanılan aşağılayıcı ve küçümseyici hükümleri Atatürk'e nakletmesiyle "Türk Tarih Kurumu"nun oluşumunu hazırlayan gelişmelere katkıda bulunmuştur. 1931 yılında Türk Tarih Kurumu'nun kurucu üyeliğine seçilen İnan, 1935 y1lında Lisans ve Lisansüstü öğrenimi için Lozan Üniversitesi'ne gönderilmiştir. 1939 yılında doktorasını tamamlayarak yurda dönmüş ve Dil ve Tarih-Coğrafya Fakültesi'nde 1942 yılında Doçent, 1950 yılında ise Profesör olmuştur. Prof. Dr. A. Afet İnan, 1973 yılında Dil ve Tarih-Coğrafya Fakültesi'nde "Türkiye Cumhuriyeti Tarihi Kürsüsü"nün kurulmasına öncülük etmiş ve aynı kürsüden 1977 yılında emekliye ayrılmıştır. Atatürk'ün çok yakınında bulunan ve Türkiye Cumhuriyeti Tarihi'ne ilişkin pek çok bilimsel yayını bulunan Prof. Dr. A. Afet İnan, 1985 yılında vefat etmiştir.

\section{Prof. Dr. Nejat Kaymaz:}

1953 yılında Ankara Üniversitesi Dil ve Tarih-Coğrafya Fakültesi Tarih Bölümü'nden Genel Türk Tarihi, Yeniçağ Tarihi, Yakınçağ Tarihi ve Farsça sertifikaları alarak mezun olan Kaymaz, 1954 yılında Genel Türk Tarihi Kürsüsü'ne Asistan olarak atanmı̧̧ır. Aynı Fakültede 1958'de Doktor ve 1967'de Doçent unvanı alarak, 1977 yılında Cumhuriyet ve Türk Devrim Tarihi Kürsüsüne geçmiştir. 1977 y 1ìnda kürsü başkanlığı ve Türk İnkılap Tarihi Enstitüsü Müdürlüğü görevine atanan Kaymaz, 1983 yılında Profesör olmuş̧ur. Türkiye Cumhuriyeti Tarihi konularında eserleri bulunan Prof. Dr. Nejat Kaymaz, Dil ve Tarih-Coğrafya Fakültesi Cumhuriyet Tarihi Anabilim Dalı Başkanı iken emekliye ayrılmıştır.

\section{Prof. Dr. Yaşar Yücel:}

1934 yılında Urfa'da doğan Yücel, Ankara Üniversitesi Dil ve TarihCoğrafya Fakültesi Tarih Bölümiì'nden 1958 yılında mezun olmuştur. Askerlik görevini takiben 1960 yılında adı geçen Fakültenin Yeniçağ Tarihi Kürsüsü'ne Asistan olarak girmiştir. 1963 yılında Doktor ve 1969 yılında ise Üniversite Doçenti unvanlarını alan Yücel, 1975 yılında Yeniçă̆ Tarihi Kürsüsü'ne Profesör olarak atanmıştır. Prof. Dr. Yaşar Yücel, 1977-1982 yılları arasında iki dönem Dil ve Tarih-Coğrafya Fakültesi'nin Dekanlık görevini ve Tarih Bölümü Başkanlığını yürütmüştür. Bunların yanı sıra Türk İnkılap Tarihi Enstitüsü Müdürlüğ̈̈, Türk Tarih Kurumu, Üniversitelerarası Kurul ve Milli Komite Üyeliği görevlerinde bulunmuştur. Çeşitli üniversite ve askeri okullarda Atatürk hakkında konferanslar veren Prof. Dr. Yaşar Yücel'in, Osmanl1-Cumhuriyet Tarihi ile ilgili pek çok eseri mevcuttur.

\section{Prof. Dr. Aydın Taneri:}

1932 yılında İstanbul-Kadıköy'de doğan Taneri, 1959 yılında Ankara Üniversitesi Dil ve Tarih-Coğrafya Fakültesi Tarih Bölümü'nden mezun olmuştur. 1962 yılında adı geçen Fakülteye Asistan olarak atanarak 1967'de 
Doktor, 1972'de Doçent unvanını almaya hak kazanmıştır. 1978 yılında Profesör olan Taneri, 1982 yılından itibaren üniversitedeki derslerine ek olarak İnkılap Tarihi dersleri vermeye başlamıştır. Ankara Üniversitesi Türk İnkılap Tarihi Enstitüsü Müdürlüğü görevinde de bulunan ve çok sayıda yayını olan Prof. Dr. Aydın Taneri, 1 Aralık 1997 yılında vefat etmiştir.

\section{Prof. Dr. Mustafa Kafalı:}

1934 yılında Konya'da doğan Kafalı, Ankara Üniversitesi Dil ve TarihCoğrafya Fakültesi Tarih Bölümü'nden mezun olmuştur. 1960 yılında İstanbul Üniversitesi Edebiyat Fakültesi'nin Umumi Türk Tarihi Kürsüsü’ne Asistan olarak girmiştir. 1965 yılında Doktor unvanını alarak, 1971-1972 yıllarında bir yıl üniversite kontenjanıyla Londra'ya giderek ilmi incelemelerde bulunmuştur. 1973 yılında Doçent ve 1982 yılında Profesör olan Kafalı, uzun yıllar Dil ve Tarih-Coğrafya Fakültesi'nde öğretim üyeliği görevini sürdürmüştür. Türk İnkılap Tarihi Enstitüsü Müdürlüğü ve Türk Tarih Kurumu üyeliği görevlerinde de bulunan Prof. Dr. Mustafa Kafalı'nın pek çok ilmi çalışması mevcuttur.

\section{Prof. Dr. Hasan Köni:}

1946 yılında İstanbul'da doğan Köni, Sen Josef Lisesi'ni ve Ankara Üniversitesi Siyasal Bilgiler Fakültesi'ni bitirmiştir. Aynı Fakültede ve Michigan State Üniversitesi'nde Lisansüstü ve Doktora çalışmalarını yapmıştır. 1982 yılında California Ưniversitesi, Santa Cruz'da ve 1990-1991 yilında Washington, John Hopkinks Üniversitesi'nde konuk öğretim üyesi olarak bulunmuştur. Ankara Üniversitesi Türk İnkılap Tarihi Enstitüsü Müdürlügüü, Siyasal Bilgiler Fakültesi Uluslararası İlişkiler Bölümü Öğretim Üyeliği, Atatürk Kültür Dil ve Tarih Yüksek Kurumu Yönetim Kurulu Üyeliği ve Milli Güvenlik Akademisi Öğretim Üyeliği görevlerinde bulunmuştur. Türk Dış-İç Politikası ve Atatürk üzerine uluslararası ve güncel konularda yayınlanmış altmışa yakın makalesi ve eseri bulunmaktadır.

\section{Prof. Dr. Hikmet Yavuz Ercan:}

1940 yılında Malatya'da doğan Ercan, ilk ve orta öğrenimini bu şehirde tamamlamıştır. Ankara Üniversitesi Dil ve Tarih-Coğrafya Fakültesi Tarih Bölümü'nden mezun olduktan sonra bir süre Tarsus Lisesi'nde tarih öğretmenliği yapmıștır. 1967 yılında mezun olduğu fakültede araştırma görevlisi olan Ercan, 1972'de “Osmanlı İmparatorluğu'nda Müslüman Olmayan Halkın Hukukî ve İçtimaî Durumu" konulu doktora tezini tamamlamıştır. 1972-1974 tarihleri arasında askerlik görevini tamamladıktan sonra 1979'da "Osmanlı İmparatorluğu'nda Bulgaristan ve Voynuklar" konulu teziyle Doçentliğe, 1988 'de "Kudüs Ermeni Patrikhanesi" konulu teziyle Profesörlüğe yükseltilmiştir. 1976-1977 yılları arasında İngiltere'de araştırma ve incelemelerde bulunarak, 1989 yılında Japonya'da misafir profesör olarak bir dönem ders vermiştir. Yurtiçinde ve dışında çeşitli 
bilimsel toplantılara katılarak bildiriler sunan Prof. Dr. Yavuz Ercan, dokuz yıl Kara Harp Okulu'nda, iki yıl İnönü Üniversitesi'nde, bir yıl Gazi Üniversitesi'nde, sekiz yıl Ortadoğu Teknik Üniversitesi'nde ve iki yll Bilkent Üniversitesi'nde, part-time öğretim üyesi olarak lisans düzeyinde; Gazi Üniversitesi Sosyal Bilimler Enstitüsü'nde bir dönem, Anadolu Üniversitesi Sosyal Bilimler Enstitüsü'nde on bir yıl yüksek lisans ve doktora dersleri vermiştir. Halen Ankara Üniversitesi sosyal Bilimler Enstitüsü ve Türk İnkılap Tarihi Enstitüsü'nde yüksek lisans ve doktora dersleri, Dil ve Tarih-Coğrafya Fakültesi'nde lisans dersleri vermektedir.

Prof. Dr. Yavuz Ercan, on sekiz yıl Türk Tarih Kurumu aslî üyeliği, aynı kurumda Basımevi Komisyonu Başkanlığı, iki yıl Milli Eğitim Bakanlığı Talim ve Terbiye Kurulu Danışmanlı̆̆ı, on üç yıl Ankara Üniversitesi Osmanlı Tarihi Araştırma Merkezi Müdürlüğü, iki yıl Türk İnkılap Tarihi Enstitüsü Yönetim Kurulu Üyeliği, yirmi iki yıl Genelkurmay Askeri Tarih ve Stratejik Etüt Başkanlığı'nda Türk Askeri Tarih Komisyonu Yürütme Kurulu üyeliği yapmıştır. Halen Türk İnkılap Tarihi Enstitüsü Müdürlüğü, Genelkurmay Askeri Tarih ve Stratejik Etüt Başkanlığı Atatürk Araştırma Merkezi Genel Kurul Üyeliği, Dil ve Tarih-Coğrafya Fakültesi Genel Türk Tarihi Anabilim Dalı Başkanlığı, Ankara Üniversitesi Stratejik Araştırmalar Merkezi Müdürlüğü görevlerini de yürütmektedir.

Yayınlanmış sekiz kitap ve elliden fazla makalesi vardır. Yayınlarının biri Almanca, üçü İngilizce, diğerleri Türkçe'dir. Türk Tarih Kurumu yayınları arasında çıkan "Osmanlı İmparatorluğu'nda Bulgarlar ve Voynuklar" başlıklı kitabı 1986 yılında Türk Kültürüne Hizmet Vakfı ödülünü kazanmıştır. Bu kitap Bulgarca'ya da çevrilip Bulgaristan'da yayınlanmıştır. Prof. Dr. Yavuz Ercan evli ve iki çocuk babasıdır. 
Resmi Gazete

20 Ilaziran 1935 Perșembe

Saly1-3033

Sayfa: 5.372 'de

Ankarà'da bir Dil ve Tarih - Coğrafya Fakültesi Kurulması Üæerine Kanun

Madde I- Ankara'da bir (Dil ve Tarih-Coğrafya Fakültesi) açmak için Kültür Bakanhı̆mma yetki verilmiștir.

Maddde 2- 13u fakiulteyi yönetecech işyarlarmn derece, salyı ve aylıklanı ilişik (1) sayılı çizelgede gösterilmiş̧tir.

Bu çizelgede gösterilen işyarlar kadrosu Maarif Vehäleti merkez teşkilat ve vazifcleri hakkındaki 2287 sayılı kanunun 23. maddesine bağı çizelgeye eklenmiştir.

Madde 3- Fakültece talebeden alınacak yazılma, okuma, yoklama, seminer ve șahadeıname harç ve kesencklerinin tutarı ve toplanması yolları Finaus ve Käiliür bakan!armea kararlaștırılır.

Makkle 4- Vakültenin ägretim ve yënctim işleri Küllür Bakanlığıtca yapılacak bir ögrenekle saptanır.

Muvakkat madde I. Fakültenin bağh (2) sayılı çizelgede gösterilen uzamanlarla yönetim işyarları kadrosu 1935 mali yılı Muvazenei Umumiye kanunumun 5. maddesine bağlı (1)) cetvelinin Kültür Bakanlığı kısmına eklenmiştir.

Muvakkat madde 2- läkíltede 1935 mali yıh içinde kullanılacak kesenekli ŏğretımenler kadrosu ile tâkültenin bütủn masrafları Kültür Bakanlığını 1935 mali yılı bütçesine konulacak paraya göre Bakanlar Kurulunca saptanır.

Madde 5- Bu kanun yaym tarihinden yürïr.

Madde 6- Bu kanunun hükümlerini Finans ve Kültür Bakanları yürütür.

$20 /(\%) / 1935$

"2287 numaralı kanun, 24 34 sayılı Resmi gazetededir"

EK-1: “Ankara'da Bir Dil ve Tarih-Cografya Fakültesi Kurulması Üzerine Kanun”, Resmi Gazete, 20 Haziran 1935, No. 3033, s. 5372. 
Ankara Dil ve Tarih - Coğrafiye Fakültesine băğı "Türk Inkilâp Tarihi Enstïtüsü" kurulması hakkmda kanun'

$$
\text { (:5 nisan 1212) }
$$

Madde 1 - Ankara Dil ve Tarih - Cnx̌rafya Fakïltesine bax̌lı bir "Tork Inkılâp Tarihi Enstitüsia" kurulmuştur. Ru Fnstitünün vazife. Seri şunlardır :

औ) Turk Istiklâl Savą̧, Türk Inkılâbı ve Türkiye Cumhuriyeti refiminin dacandı̆̆ı esaslar hakkında her türlü araștırmalarda bulun mak:

5) Bu konularla ilgili belgeleri ve yayınları toplıyarak kütüphane ve müzeler meydana getirmek ve bir arşiv kurmak;

c) Türk Inkilâp ve Rejimini memileket içinde ve dışında tanıtmak çin deraler ve konferanslar rermek ve her türlü yayınlarda bulunmak.

Madde 2 - Fakoltelerde ve yüksek okullardaki Inkılâp Tarihi ve Turkiye Cumhurigeti Rejimi dersleri Maarif Vekilližince hazırlanaca' porxramlara ve tàyin edilecek esaslara göre bunların kendi kad. rolanndaki razifeli profesör, doçent ve öğretmenleri tarafından okutolite.

Madde 3 - Bütün resmî daire ve makamlarla belediyeler, milì Kurumlar kendi dosya ve arşivlerinde bulunan ve Istiklâl ve Inkilâp Tarihigle ilgili olan her türlü evrak ve belgelerin asıl veyà suretlerini ve egralan Maarif Vekilliği tarafından lüzum gösterildikçe Türk Inbläs Tarihi Enstitüsüne verirler.

lstikislal ve Inkılâp tarihiyle ilgili olup her ne suretle olursa olsun

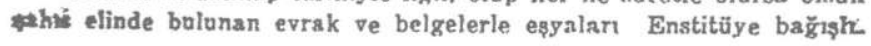

1 Nead: 22 nisan 1942 - Resmi Gazete No. 5090

EK-2 (a): "Ankara Dil ve Tarih-Coğrafya Fakültesi'ne Bağlı 'Türk Inkılap Tarihi Enstitüsü' Kurulması Hakkında Kanun”, Resmi Gazete, 22 Nisan 1942, No. 5090, s. 271. 
Na ganların adları Enstitüde bulundurulacak "Seref defteri" ne yazlir ve

- 204 ayrica Resmĩ Gazete ve radyo ile ilān olunduktan sonra kendilitrine bir "Sèref Diploması" verilir.

Yukarıda yazılı evrak, belge ve escyalar, istedikleri takdircle sahip-

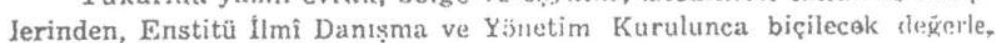
satin alınir.

Bu kanunla ilgili evrak, belge ve eșyayı özel koleksiyonlarmda bulundurmak istiyenlerden bunlarm konuları ve vasıfları hakkında Enstitüye bilgi verenlerin adları da "Seref defteri" ne ayrica vazılıt.

Yukarıki fıkıalarda yatzıl evrak, belge ve eșyanın Türkigedell çkarılması yasaktır.

Madde 4 - Enstitünün așağıdı yazılı zatlardan kurulan bir "Ilmí Danışma ve Yönetim Kurulu" vardır:

a) Fnstitü Müdürii;

b) Fakülte ve yüksck okullarrla "Inkılâ!" Tarihi ve Türkiy: ('umhuriyeti Rejimi" dersi veren profesör ve doçentler;

c) Cumhuriyet. IIalk Partisinin, Türk Tarih ve Dil Kurunlarmun Merkez ldare Ileyelleri $\hat{A}$ malarmdan memur edecekleri birer miimessil;

d) Marif Ve:killiğines memur etlilecek ïç \%at.

Kurulum kararları Maarif Vekilliğince onaylanır ve yürüttälïr.

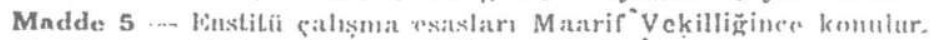

Madda 6 -... \$656 ve 3888 salytl kaummlara' ekli (1) numaralı cetvellerin Manrif Vekilliği kısınmdaki “Ankara 1)il veTarih - (nğrafya Frkihltoni" kadrolarına işhu kauma ckli (1) ve (2) numaral cetvel-

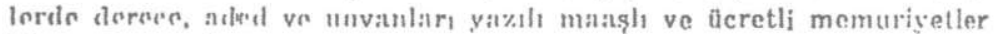
ilave olummuşur.

Muvakkn! Madde 1 ... 1042 saylh l!41 Muvazenei Umuniye Ka.

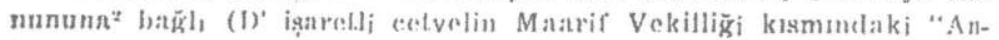
karn bil ve 'Tarih - (Eoğrafya lakültesi" milstahdemleri ara:alla islan

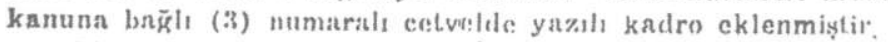

Muvaklsnt Madde 2 -_. 'T'ïrk Inkılâp 'l'itrihi Ènstitüsinün her fïrlü

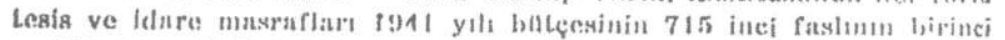
ve ikinci maddelerindeki tahsisattun verilir.

Madde 7 - Bu kanunun hilkmii neşri tarihinden haşlar.

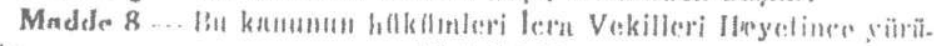
Lalill. $17 / 1 / 1940$

(n)

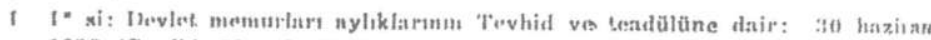
1939 (S. eilt: 20 , snh. 535 )

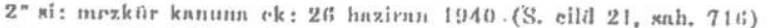

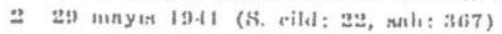


15 Nisan 1942 - Kanunlar - Niz - Tal - 15 Nissn 1912

273

(1) numaralt celvel

\begin{tabular}{llcc} 
Derece & Memuriyetin nev'i & Aded & Maaș \\
\hline 8 & Türk Inkılâp Tarihi Fnstitüsü Müdür Muavini & 1 & 50 \\
9 & Kütüphane memuru & 1 & 40 \\
9 & Arşiv Memuru & 1 & 40 \\
9 & Müze Memuru & 1 & 40
\end{tabular}

(2) nunarals cotvel

Derece Memuriyelin nev i Acled Ücret

8 Türk İnkılâp Tarihi Enstitiisü Müciürüi $1 \quad 140$

(3) numaralı cetvel

Dosya Mcmuru ve Daktilo

IIademe: 


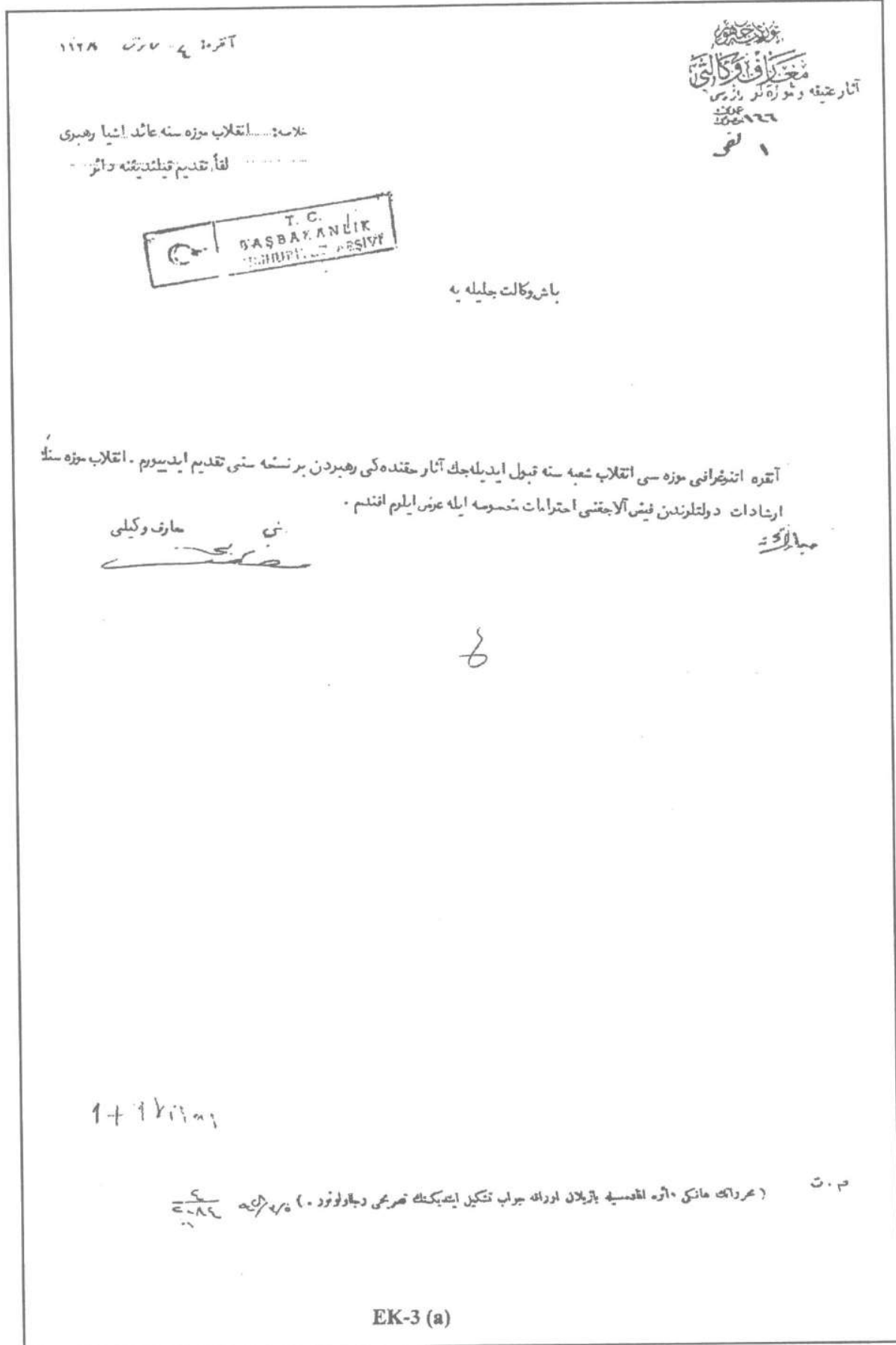




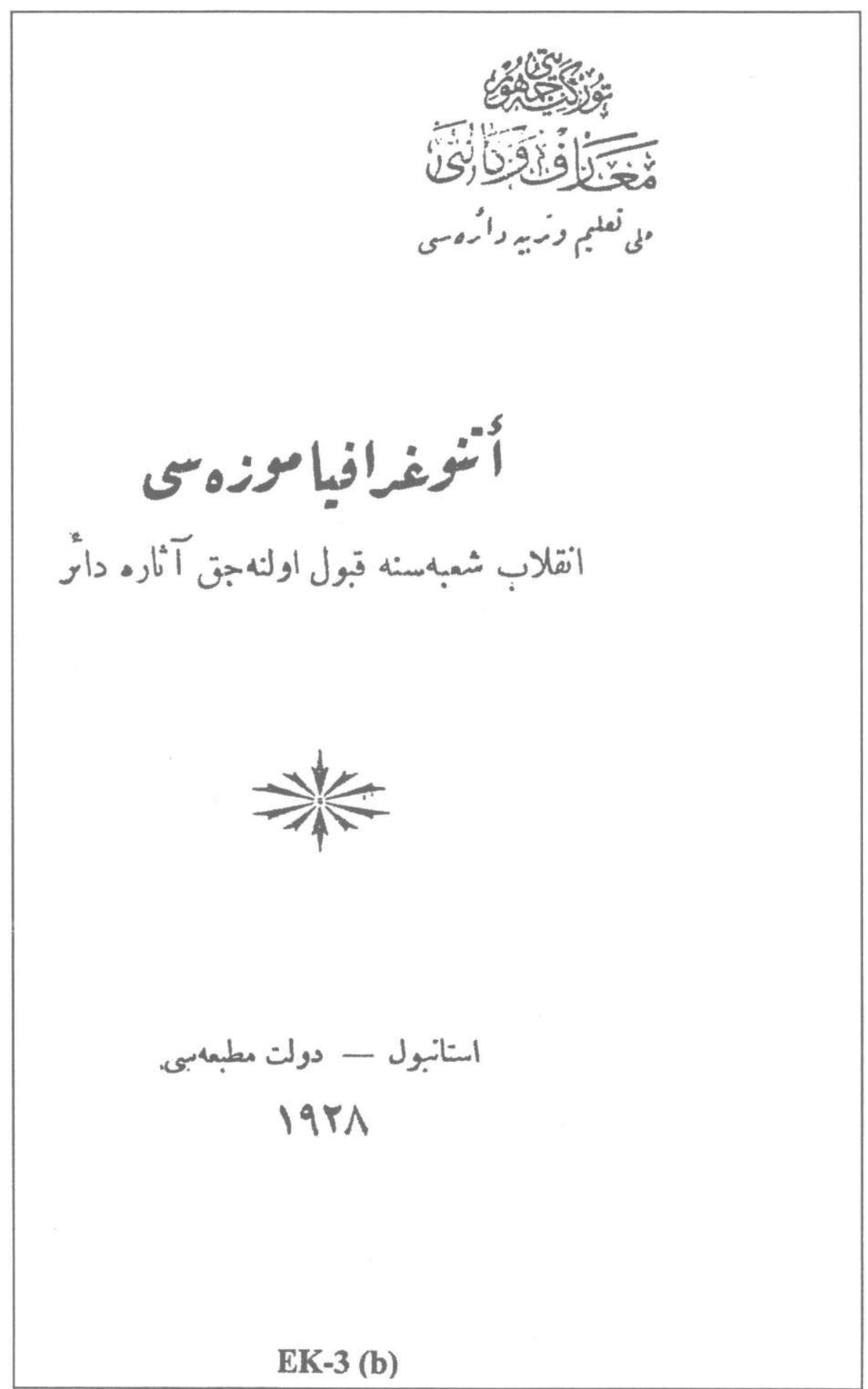




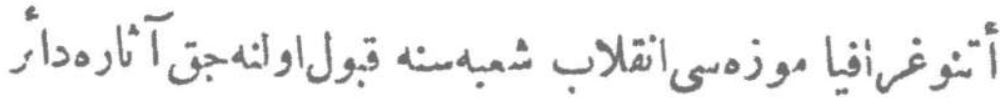

- 1

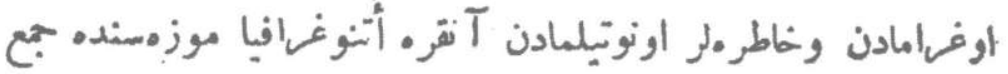

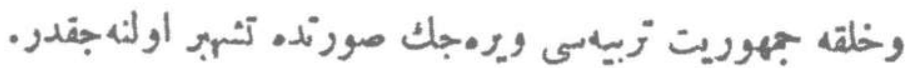

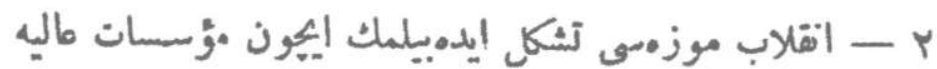

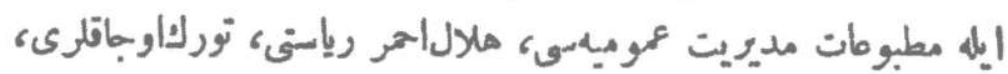

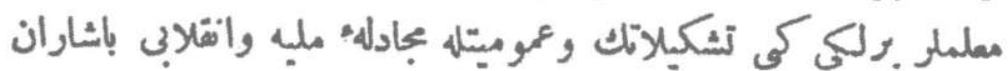

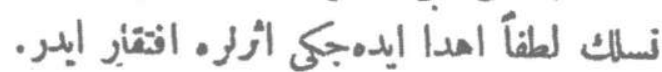

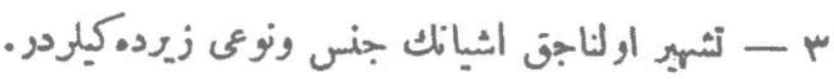

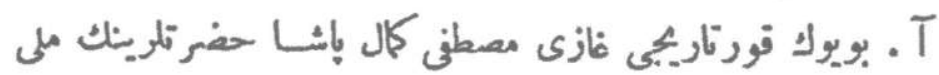

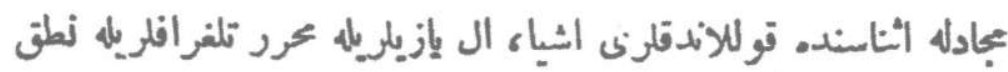

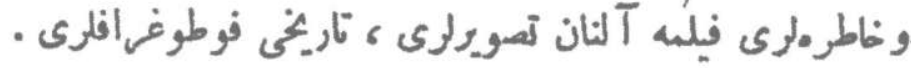

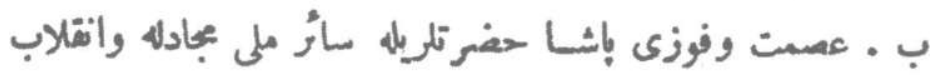
اركانك قوللامثش اولدقلزى تاريخى اشيا وفوطوغ افلرى .

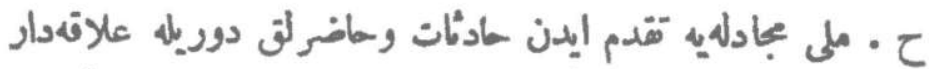

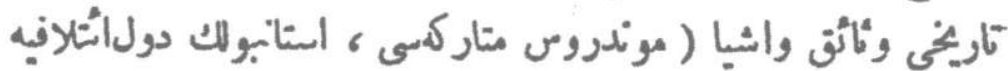

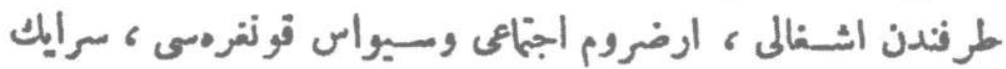

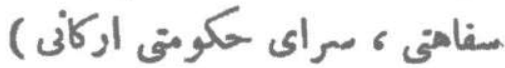
ع - ملى بجادلا وياخود استقلال حربى دوردمى • 


\section{$-r$}

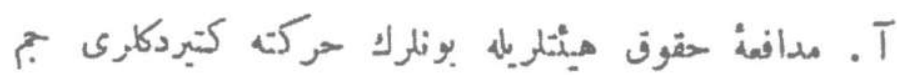

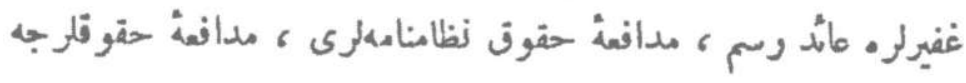

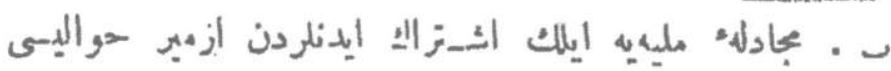

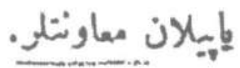

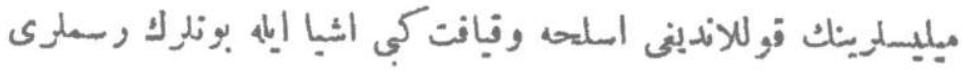

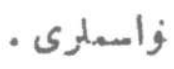

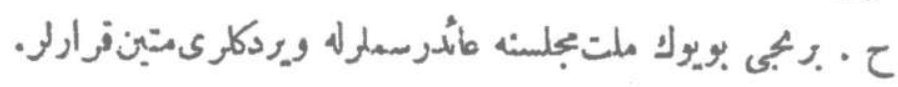

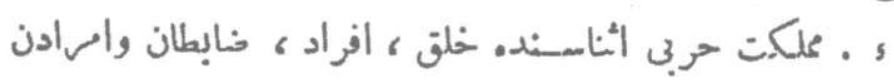

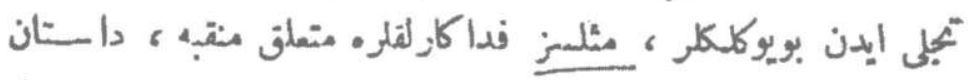

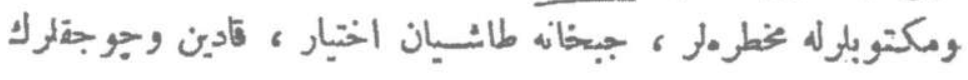

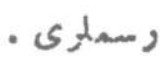

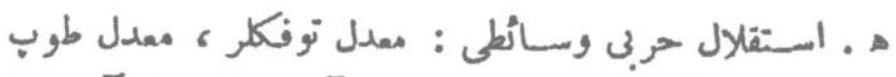

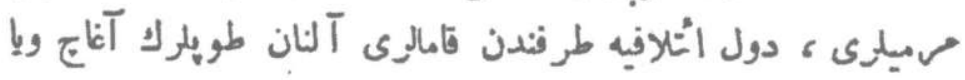

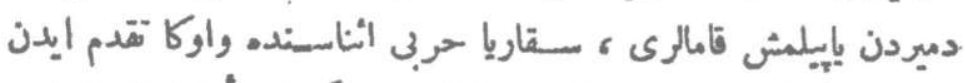

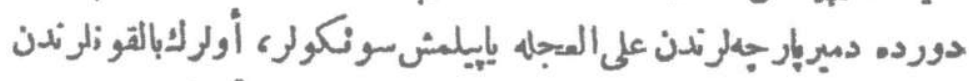

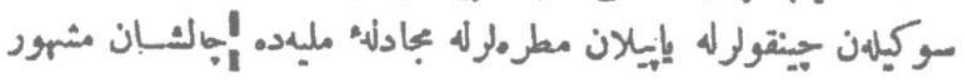

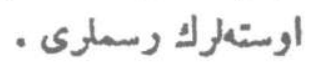

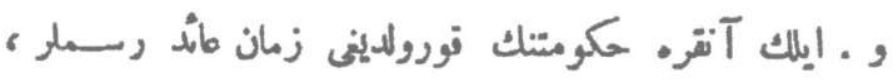

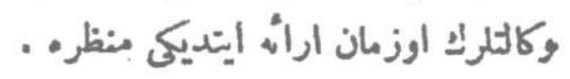

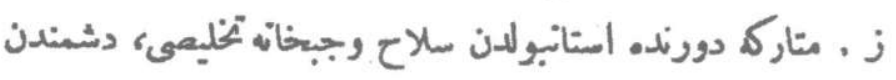

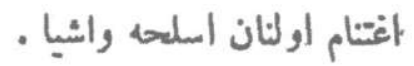

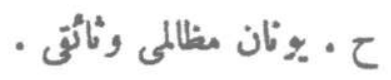

EK-3 (d) 


\section{$-\mathfrak{\varepsilon}$}

ط · بويوك آعرض واونى آهقبب ايدن مسعود قورتولوثن. ازمير.

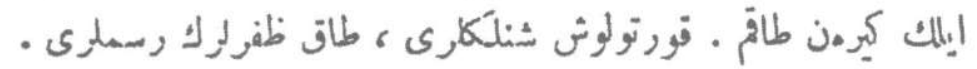

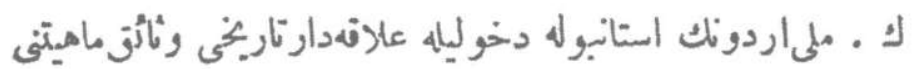

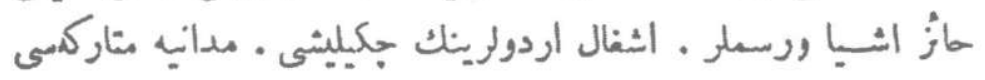

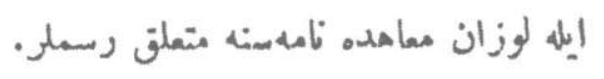

ل . مجهول عسكر آبدمسى (كوجيوك نمونهى ويا رسمى ) شهدا

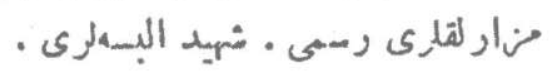

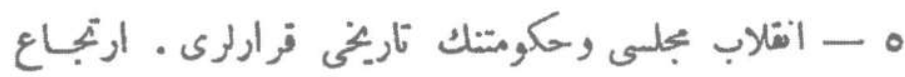

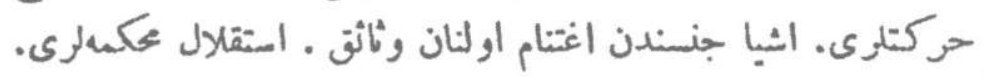

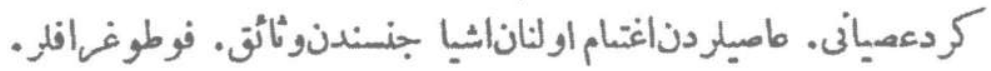

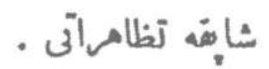
: 1 - رئس جهور حضر تلرينك استانبول سباحقى انطباعلرى. V - - اتقلابك فيضلىتنيجهارى. دمير يوللرى . العمار حر كتلرى.

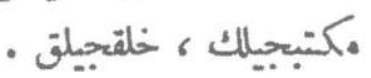

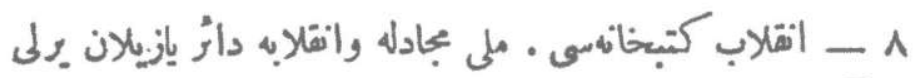

$$
\text { واجنى آثمار. }
$$

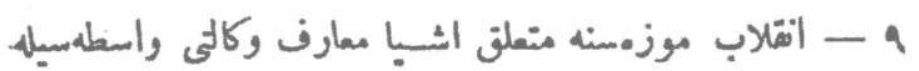
ياخود دوغهيدن دوغىىيه موزميه كوندريلير.

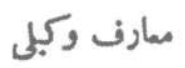

EK-3 (e) 
Maarif Vekâleti

Âsâr-1 atîka (Eski Eserler) ve Mevzû́lar Daîresi

Ankara: 4 Mart 1928

Hulâsa (Özet): Inkulâb Müzesi'ne aid eşya rehberi leffen (zarf içine konularak) takdim kılındığına daîr.

Başvekâlet-i Celîleye

Ankara Etnoğrafya Müzesi Inkalâb Şubesi'ne kabul edilecek âsâr hakkndaki rehberden bir nüshasını takdim ediyorum. Inkalâb Șubesi'nin iş̧âdât-1 devletlerinden feyz alacağını ihtirâmât-1 mahsûsa (ð̌zel saygı) ile arz eylerim efendim.

Mustafa Necati Maarif Vekili

(Muharrerâtun hangi daire ifadesiyle yazılan evraka cevap teşkil ettiginin tarihi rica olunur.)

EK-4(a): Başbakanlık Cumhuriyet Arşivi, "Türkiye Cumhuriyeti Maarif Vekâleti Milli Tâlim ve Terbiye Dâiresi, Etnoğrafya Müzesi Inkalâp Şubesi'ne Kabul Olunacak Asâra Dair", 030. 10. 213. 445.9. 


\section{Türkiye Cumhuriyeti}

Maarif Vekâleti

Milli Talim ve Terbiye Dairesi

ETNOĞRAFYA MŨZESÍ

İNKILÂB ŞUBESI'NE KABUL OLUNACAK ÂSÂRA DAİR

Ístanbul - Devlet Matbaası

1928.

EK-4 (b) 


\section{ETNOĞRAFYA MOZZESI INKILÂB ŞUBESI'NE KABUL OLUNACAK ÂSÂRA DAİR}

1. Mũcadele-i Milliye ve mes'ûd-1 inkılâbiyeye müteallik vesaik ve eşya zâyi'e uğramadan ve hatıralar unutulmadan Ankara Etnoğrafya Müzesi'nde cem' ve halka Cumhuriyet terbiyesi verecek surette teșhir olunacaktur.

2. İnkalâb Müzesi teşkil edebilmek için müessesât-1 âliye ile Matbuat-1 Müdüriyet-i Umumiyesi ve Hilâl-i Ahmer Riyaseti, Türk Ocaklan, Muallimler Birliği gibi teşkilâtın ve umumiyetle Mücadele-i Milliye ve Inkılâbı başaran neslin lütfen ihda' (hediye) edeceği eserlere iftikâr eder ( çok ihtiyacı vardır).

3. Teşhîr olunacak eşyanın cins ve nev'î zîrdekilerdir.

a) Büyük Kurtancı Gazi Mustafa Kemal Paşa Hazretleri'nin Millî Mücadele esnasında kullandıklarn eşya ve el yazılanyla muharrer telgraflarıyla Nutuk ve hatıralan, filme alınan tasvîleri, tarîhi fotoğrafları.

b) Îsmet ve Fevzi Paşa Hazretleriyle saîr Millî Mũcadele ve Inkalâb erkâninin kullanmış olduklan tarîhi eşya ve fotoğrafları.

c) Millî Mücadele'ye tekâddưm eden hadîsât ve hazırlık devriyle alâkadâr tarihî vesâik ve eşya (Mondros Mütarekesi, Istanbul'un Düvel-i Itilâfiye tarafindan işgali ve Erzurum içtima'1 ve Sivas Kongresi ve sarayın sefahati ve Saray Hükümeti Erkân)

4. Millî Mücadele veyahûd İstiklâl Harbi devresi. 
a) Müdâfaa-i Hukuk heyetleriyle bunların harekete getirdikleri Cemm-i gafîrlere aid resim, Müdâfaa-i Hukuk Nizâmnameleri, Müdâfaa-i Hukuklarca yapılan mu'avenetler (yardımlar).

b) Mücâdele-i Milliye'ye ilk iştirâk edenlerden Izmir havâlisi milislerinin kullandığı eslihâ ve kıyafet gibi eşya ile bunların resimleri ve isimleri.

c) Birinci Büyük Millet Meclisi'ne aid resimlerle verdikleri metîn kararlar.

d) Memleket Harbi esnasında halk ve efrâd ve zabitân ve ümerâdan tecellî eden büyüklükler, misâlsiz fedakârlıklara müteallik (ilgili) menkıbe, destan ve mektublarla muhtıralar, cebhane taşıyan ihtiyar, kadın ve çocuklann resimleri.

e) Istiklâl Harbi vesâiti: Muâdil (eşdeğer-denk) tüfekler, muâdil top mermileri, Düvel-i İtilâfiye tarafindan kamalan alınan toplanın ağaç veya demirden yapılmış kamaları, Sakarya Harbi esnasında ve ona takâddüm eden devirde demir parçalanndan alelacele yapılmış süngüler, evlerin balkonlarından sökülen çinkolarla yapılan mataralarla Mücadele-i Milliye'de çalışan meşhur ustalann resimleri.

f) Ilk Ankara Hükümeti'nin kurulduğu zamana aid resimler ve vekâletlerin o zaman ira'e ettiği (gösterdikleri) manzara.

g) Mütareke devrinde İstanbul'dan silâh ve cebhane tahlîsi (kaçınlması), düşmandan iğtinâm olunan (ele geçirilen) esliha ve eşya.

h) Yunan mezâlimi vesâiki. 
1) Büyük Taarruz ve onu ta'kîb eden mesûd kurtuluş. Izmir'e ilk giren takım. Kurtuluş şenlikleri ve tâk-1 zaferlerin resimleri.

j) Millî ordunun Istanbul'a duhulưyle alâkadâr tarihî vesaîk mahiyetini haiz eşya ve resimler. Işgâl ordulannın çekilişi. Mudanya Mütarekesi ile Lozan Mu'ahede-nâmesine müte'âllik (iliş̧kin) resimler.

k) Meçhul Asker Âbidesi (Küçūk numunesi veya resmi). Şühedâ (şehit) mezarlıkları resmi. Şehit elbiseleri.

5. Inkalâb Meclisi ve Hükümetinin tarihi kararlar. Irtica hareketleri. Eşya cinsinden iğtinâm olunan vesâik. İstiklâl Mahkemeleri. Kürd İsyam. Asilerden iğtinâm olunan (ele geçen) eşya cinsinden vesâik. Fotoğraflar. Şabka tezâhürâtı.

6. Reis-i Cumhur Hazretleri'nin Istanbul seyahati intibâ'ları.

7. Inkılâb'ın feyizli neticeleri. Demiryolları. Imar hareketleri. Mektebcilik, halkçılık.

8. Inkılâb Kütulbhanesi. Millî Mücadele ve Inkılâba dair yazılan yerli ve ecnebi âsâr.

9. Inkilâb Müzesi'ne milte'allik eşya Maarif Vekâleti vasitasıyla yahud doğrudan dogruya müzeye gönderilir.

Maarif Vekili 